\title{
Erratum to: Health-Related Quality of Life in Patients with Multiple Sclerosis: Impact of Disease-Modifying Drugs
}

\author{
Peter Joseph Jongen ${ }^{1,2}$
}

Published online: 7 July 2017

(C) Springer International Publishing AG 2017

\section{Erratum to: CNS Drugs DOI 10.1007/s40263-017-0444-x}

An Online First version of this article was made available online at http://link.springer.com/journal/40263/online First/page/1 on 12 June 2017. A number of errors were subsequently identified in the article, and the following corrections should be noted:

Page 2, column 1, line 8: The text, which previously read:

“ ... INF $\beta-1 \mathrm{~b}$, pegylated INF $\beta-1 \mathrm{a} . . . "$ should read:

“... IFN $\beta-1 \mathrm{~b}$, pegylated IFN $\beta-1 \mathrm{a} . . . "$

Page 6, Table 2, 'Outcome' column, line 1: The text, which previously read:

“... LMSQOL score ...” should read:
“... LMSQoL score ..."

Page 9, column 1, line 3: The text, which previously read:

“... INF $\beta-1$ - ..." should read:

“... IFN $\beta-1 \mathrm{a} . . . "$

Page 11, column 2, line 11: The text, which previously read:

“... INF $\beta \ldots$... should read:

"... IFN $\beta \ldots "$

Page 11, column 2, line 20: The text, which previously read:

“... INF $\beta-1$ - ..." should read:

“... IFN $\beta-1 \mathrm{a} . . . "$

The online version of the original article can be found under doi:10.1007/s40263-017-0444-x.

Peter Joseph Jongen

p.j.h.jongen@rug.nl

1 Department of Community and Occupational Medicine, University Medical Center Groningen, Antonius Deusinglaan 1, 9713 AV Groningen, The Netherlands

2 MS4 Research Institute, Ubbergseweg 34, 6522 KJ Nijmegen, The Netherlands 